ступенів № 123 м. Харкова» [Електронний ресурс]. - Режим доступу до документа: http://www.mon.gov.ua/laws/ MON_800_07.doc 10. Овчарук О. В. Компетентнісний підхід до формування змісту середньої освіти:досвід зарубіжних країн. Компетентнісний підхід у сучасній освіті:світовий досвід та українські перспективи (Бібліотека 3 освітньої політики) / [за заг. ред. О. В. Овчарук]. - К. : «К.І.С.», 2004. - С. 5-15. 11. Петровская Л. А. Компетентность в общении / Л. А. Петровская. - М., 1989. - 216 с. 12. Пометун О. І. Формування громадянської компетентності: погляд 3 позиції сучасної педагогічної науки / О. І. Пометун // Вісник програм шкільних обмінів. - 2005. - № 23. - С. 18. 13. С тепко М. Ф. Компетентнісний підхід до організації підготовки фахівців, його розуміння і проблеми використання у вищій школі України / М. Ф. Степко // Педагогіка і психологія: вісник АПН України. - 2009. - № 2. - С. 44-50. 14. Хазова С. А. Показатели конкурентноспособности как критерии профессиональной компетентності специалистов по физической культуре и спорту [Электронный ресурс] / С. А. Хазова. - Peжим доступа: http: //www.adygnet.ru/konfer/konfifk2006/soob/3/3 Hazova.htm 15. Хомський Н. Аспекты теории синтаксиса / Н. Хомський. - М., 1972. - 259 с. 16. Хударковський К. І. Компетентнісний підхід як основа стратегії управління якістю освіти / К. І. Хударковський, А. І. Комишан // Проблеми інженернопедагогічної освіти. - 2007. - № 16. - С. 44-50. 17. Хуторской А. В. Ключевые компетенции и образовательные стандарты [Электронный ресурс] / А. В. Хуторской // Отделение философии образования и теоретической педагогики РАО. - Центр «Эйдос». - Режим доступа: www.eidos.ru/journal/2002/0423.htm; http //www.eidos.ru /news/compet. htlm. 18. Definition and Selection of Competencies. Theoretical and Conceptual Foundations (DESECO). - Strategy Paper on Key Competencies. - An Overarching Frame of Reference for an Assessment and Research Program - OECD (Draft). - 279 p.

\title{
ГАЛУЗЕВІ СТАНДАРТИ ВИЩОЇ ОСВІТИ НОВОГО ПОКОЛІННЯ - ЗАПОРУКА ПІДГОТОВКИ ПРОФЕСІЙНО КОМПЕТЕНТНОГО ФАХІВЦЯ
}

У статті розкрито особливості розроблення галузевих стандартів вищої освіти на засадах компетентнісного підходу на прикладі підготовки педагогів професійного навчання будівельного профілю.

Ключові слова: галузевий стандарт вищої освіти, компетентнісний підхід, компетентність, компетениії, педагог професійного навчання. 
В статье раскрыты особенности разработки отраслевых стандартов высшего образования на основе компетентностного подхода на примере подготовки педагогов профессионального обучения строительного профиля.

Ключевые слова: отраслевой стандарт высшего образования, компетентностный подход, компетентность, компетенции, педагог профессионального обучения.

The article is devoted to the peculiarities of higher education standarts work out on the basis of competence approach on the pattern of pedagogues' training for professional teaching in civil engineering branch.

Key words: educational standart in branch, competence aproach, competence, competence, professional teaching pedagogue.

Вимоги до фахівців 3 вищою освітою, які постійно змінюються 3 боку суспільства та ринку праці, зумовили необхідність перегляду освітнього процесу та його результатів. Провідним завданням постає формування здатності фахівця на основі відповідної фундаментальної освіти перебудовувати систему власної професійної діяльності 3 урахуванням соціально значущої мети та нормативних обмежень, тобто формування особистісних характеристик майбутнього фахівця. Якщо визначити за головну мету діяльності системи вищої освіти підготовку такого фахівця, то процес навчання доцільно організовувати так, щоб забезпечувався всебічний розвиток особистості майбутнього фахівця. Засобом формування особистості визначено освітні технології, продуктом діяльності - особистість випускника вищого навчального закладу, який має бути компетентним не лише в професійній галузі, але й мати активну життєву позицію, високий рівень громадянської свідомості, бути компетентним розв'язати будь-які завдання (задачі), які ставить перед ним життя [4].

Отже, перехід до нового покоління галузевих стандартів вищої освіти на засадах компетентнісного підходу $є$ необхідним етапом на шляху реформування системи освіти в Україні.

За даними аналізу науково-методичної літератури можемо стверджувати, що проблемі розроблення компетентнісного навчання в Україні, навіть на рівні нормативних документів підготовки фахівців освітньо-кваліфікаційного рівня «бакалавр», присвячено замало досліджень $[1 ; 2 ; 5]$. Тому метою cmammi є спроба розкрити особливості розроблення галузевих стандартів вищої освіти на основі компетентнісного під- 
ходу на прикладі підготовки педагогів професійного навчання будівельного профілю.

Застосування компетентнісного підходу до створення галузевих стандартів вищої освіти в жодному разі не замінює традиційної для вітчизняної освіти системи «знання, уміння, навички», а створює передумови для більш активного і гнучкого наближення результатів освіти до потреб і вимог ринку праці, подальшого розвитку освітніх технологій і системи освіти загалом.

У дисертаційному дослідженні нами розроблено проект ОКХ та ОПП підготовки бакалавра за напрямом 6.010104 «Професійна освіта (за профілем)» з урахуванням вимог до галузевих стандартів вищої освіти, які відображені в рекомендаціях Міністерства освіти і науки України (МОH) [3].

В основу розроблення ГСВО нового покоління нами покладено компетентнісний підхід, який, у свою чергу, повинен привести до формування нової системи діагностичних засобів із переходом від оцінки знань до оцінки компетенцій та визначення рівня компетентності загалом. Результати формування системи компетенцій є одним із ключових моментів оцінки якості знань.

Запропоноване в європейському проекті TUNING «поняття компетенцій включає знання й розуміння (теоретичне знання академічної галузі, здатність знати й розуміти), знання як діяти (практичне й оперативне застосування знань до конкретних ситуацій), знання як бути (цінності як невід'ємна частина способу сприйняття й життя з іншими в соціальному контексті)» [6]. Поняття «компетенція» включає не тільки когнітивний та операційно-технологічний складники, але й мотиваційний, етичний, соціальний, поведінковий аспекти (результати освіти, знання, уміння, систему ціннісних оріснтацій). У формуванні компетенції вирішальну роль відіграє не тільки зміст освіти, але також і освітнє середовище вищих навчальних закладів, організація освітнього процесу, освітні технології, включаючи самостійну роботу студентів тощо. Сврокомісія виокремлює 8 ключових компетенцій, якими повинен володіти кожний європеєць: компетенція в галузі рідної мови; компетенція у сфері іноземних мов; математична та фундаментальна природничо-наукова та технічна компетенції; комп'ютерна компетенція; навчальна компетенція; міжособистісна, міжкультурна та соціальна компетенції, а також громадянська компетенція; компетенція 
підприємництва; культурна компетенція.

Ці компетенції підтримуються певними здатностями, до яких зараховуються в усіх життєвих царинах такі необхідні аспекти, як критичне мислення, креативність, «європейський вимір» і активна життєва позиція.

Спільно ці здатності сприяють розвитку особистості. У сучасних умовах для випускників за напрямом підготовки 6.010104 «Професійна освіта (за профілем)» особливо важливим має бути розуміння соціального значення своєї професії i, відповідно, розуміння свого місця в системі соціальних відносин, а також здатність до критичної оцінки свого життєвого та професійного досвіду, свідомого вибору шляхів та методів удосконалення своїх особистих і професійних якостей.

Відповідність якості підготовки майбутнього педагога професійного навчання вимогам галузевого стандарту вищої освіти має визначатися його соціально-особистісними, загальнонауковими, інструментальними, загальнопрофесійними та спеціалізовано-професійними компетенціями, зміст яких подано в таблиці 1.

Таблиия 1

Соціально-особистісні, інструментальні, загальнонаукові та професійні компетенції

\begin{tabular}{|l|c|}
\hline \multicolumn{1}{|c|}{ Компетенція } & $\begin{array}{c}\text { Абревіатура } \\
\text { компетенції }\end{array}$ \\
\hline \multicolumn{1}{|c|}{ Компетенції соціально-особистісні: } & КСО \\
\hline $\begin{array}{l}\text { - розуміння та сприйняття етичних норм поведінки } \\
\text { відносно інших людей і відносно природи (принципи } \\
\text { біоетики) }\end{array}$ & КСО.01 \\
\hline $\begin{array}{l}\text { - розуміння необхідності та дотримання норм здорового } \\
\text { способу життя }\end{array}$ & КСО.02 \\
\hline - здатність учитися & КСО.03 \\
\hline - здатність до критики й самокритики & КСО.04 \\
\hline - креативність, здатність до системного мислення & КСО.05 \\
\hline - адаптивність і комунікабельність & КСО.06 \\
\hline - наполегливість у досягненні мети & КСО.07 \\
\hline - турбота про якість виконуваної роботи & КСО.08 \\
\hline - толерантність & КСО.09 \\
\hline - екологічна грамотність & КСО.10 \\
\hline - опанування додаткових кваліфікацій & КСО.11 \\
\hline - розуміння необхідності гуманного ставлення до учнів & КСО.12 \\
\hline - здатність виявляти проблеми, самостійно визначати & КСО.13 \\
\hline
\end{tabular}




\begin{tabular}{|c|c|}
\hline завдання і обирати шляхи їх розв’язання & \\
\hline $\begin{array}{l}\text { - розуміння необхідності, дотримання правил та вико- } \\
\text { нання вимог охорони праці та виробничої санітарії }\end{array}$ & КCO.14 \\
\hline $\begin{array}{l}\text { - розуміння необхідності та дотримання правил безпеки } \\
\text { життєдіяльності }\end{array}$ & КСО.15 \\
\hline Загальнонаукові компетенції: & КЗН \\
\hline $\begin{array}{l}\text { - базові уявлення про основи філософії, психології і } \\
\text { педагогіки, що сприяють розвитку загальної культури й } \\
\text { соціалізації особистості, схильності до етичних цінно- } \\
\text { стей, знання вітчизняної історії, економіки й права, ро- } \\
\text { зуміння причинно-наслідкових зв’язків розвитку сус- } \\
\text { пільства й уміння їх використовувати в професійній і } \\
\text { соціальній діяльності }\end{array}$ & КЗН.01 \\
\hline $\begin{array}{l}\text { - базові знання фундаментальних розділів математики в } \\
\text { обсязі, необхідному для володіння математичним апа- } \\
\text { ратом відповідної галузі знань, здатність використо- } \\
\text { вувати математичні методи в обраній професії }\end{array}$ & КЗН.02 \\
\hline $\begin{array}{l}\text { - базові знання в галузі інформатики й сучасних інфор- } \\
\text { маційних технологій }\end{array}$ & КЗН.03 \\
\hline $\begin{array}{l}\text { - навички використання мережевих програмних засобів } \\
\text { і навички роботи в комп'ютерних мережах }\end{array}$ & КЗН.04 \\
\hline $\begin{array}{l}\text { - уміння створювати бази даних і використовувати ін- } \\
\text { тернет-ресурси }\end{array}$ & КЗН.05 \\
\hline $\begin{array}{l}\text { - базові знання фундаментальних наук в обсязі, необ- } \\
\text { хідному для засвоєння загальнопрофесійних дисциплін }\end{array}$ & КЗН.06 \\
\hline $\begin{array}{l}\text { - базові знання в галузі, необхідні для засвоєння загаль- } \\
\text { нопрофесійних дисциплін }\end{array}$ & КЗН.07 \\
\hline $\begin{array}{l}\text { - базові знання } 3 \text { фундаментальних розділів фізики в } \\
\text { обсязі, необхідному для володіння фізичним апаратом } \\
\text { відповідної галузі знань, здатність використовувати } \\
\text { фізичні методи в обраній професії }\end{array}$ & КЗН.08 \\
\hline Інструментальні компетенції: & KI \\
\hline $\begin{array}{l}\text { - здатність до письмової й усної комунікації рідною } \\
\text { мовою }\end{array}$ & KI.01 \\
\hline $\begin{array}{l}\text { - оволодіння однією з (2-3) іноземних мов у соціальній, } \\
\text { професійній сферах, підвищення загальномовного рівня } \\
\text { у сфері ділового спілкування в колективі }\end{array}$ & KI.02 \\
\hline - уміння роботи з комп’ютером & KI.03 \\
\hline - уміння управляти інформацією & KI.04 \\
\hline - дослідницькі уміння & KI.05 \\
\hline \multicolumn{2}{|l|}{ Професійні компетенції: } \\
\hline загальнопрофесійні: & КЗП \\
\hline $\begin{array}{l}\text { - здатність обгрунтовувати практичні рішення ефектив- } \\
\text { ної організації навчально-виробничої діяльності учнів }\end{array}$ & КЗП.01 \\
\hline - здатність забезпечувати нормальний морально- & КЗП.02 \\
\hline
\end{tabular}




\begin{tabular}{|c|c|}
\hline психологічний клімат у колективі учнівської групи & \\
\hline $\begin{array}{l}\text { - здатність забезпечувати безпечні умови праці на нав- } \\
\text { чально-виробничих ділянках }\end{array}$ & КЗП.03 \\
\hline $\begin{array}{l}\text { - здатність контролювати умови праці згідно з чинним } \\
\text { законодавством }\end{array}$ & КЗП.04 \\
\hline $\begin{array}{l}\text { - здатність оформлення документації з техніки безпеки } \\
\text { згідно з чинним законодавством } \\
\end{array}$ & КЗП.05 \\
\hline $\begin{array}{l}\text { - здатність забезпечувати робочі місця технологічною } \\
\text { документацією }\end{array}$ & КЗП.06 \\
\hline $\begin{array}{l}\text { - здатність виявляти і враховувати індивідуальні особ- } \\
\text { ливості учнів }\end{array}$ & КЗП.07 \\
\hline $\begin{array}{l}\text { - здатність управляти педагогічним спілкуванням і оби- } \\
\text { рати техніку організації контакту }\end{array}$ & КЗП.08 \\
\hline $\begin{array}{l}\text { - здатність забезпечувати високий рівень культури і } \\
\text { організації навчально-виробничої діяльності }\end{array}$ & КЗП.09 \\
\hline $\begin{array}{l}\text { - здатність критично аналізувати власну професійну } \\
\text { діяльність і роботу інших }\end{array}$ & КЗП.10 \\
\hline - здатність здійснювати програми саморозвитку & КЗП.11 \\
\hline $\begin{array}{l}\text { - здатність формувати в учнів мотиваційно-ціннісну } \\
\text { сферу праці (мотиви, інтереси, потреби, здібності, обда- } \\
\text { рування) }\end{array}$ & КЗП.12 \\
\hline $\begin{array}{l}\text { - здатність визначати особливості психічного розвитку і } \\
\text { педагогічного впливу на особистість майбутнього } \\
\text { фахівця }\end{array}$ & КЗП.13 \\
\hline $\begin{array}{l}\text { - здатність здійснювати діагностику психофізіологічних } \\
\text { особливостей учнів і враховувати їх результати під час } \\
\text { організації теоретичного і практичного навчання }\end{array}$ & КЗП.14 \\
\hline $\begin{array}{l}\text { - здатність створювати комфортне навчальне середо- } \\
\text { вище }\end{array}$ & КЗП.15 \\
\hline $\begin{array}{l}\text { - здатність застосовувати комп’ютерну техніку та ін- } \\
\text { формаційні технології у професійному навчанні }\end{array}$ & КЗП.16 \\
\hline $\begin{array}{l}\text { - здатність організовувати самостійну навчальну роботу } \\
\text { учнів }\end{array}$ & КЗП.17 \\
\hline $\begin{array}{l}\text { - здатність застосовувати сучасні принципи, форми, } \\
\text { методи та засоби професійного навчання. }\end{array}$ & КЗП.18 \\
\hline $\begin{array}{l}\text { - здатність застосовувати сучасні принципи, форми, } \\
\text { методи виховання }\end{array}$ & КЗП.19 \\
\hline $\begin{array}{l}\text { - здатність співпрацювати з соціальними інститутами, } \\
\text { батьками, громадськістю } 3 \text { проблем виховання учнів }\end{array}$ & КЗП.20 \\
\hline $\begin{array}{l}\text { - здатність здійснювати дослідно-експериментальну, } \\
\text { рефлексивно-творчу діяльність }\end{array}$ & КЗП.21 \\
\hline спеціалізовано-професійні: & КСП \\
\hline $\begin{array}{l}\text { - здатність надавати допомогу в розкритті творчого } \\
\text { потенціалу, здібностей і можливостей учнів }\end{array}$ & КСП.01 \\
\hline $\begin{array}{l}\text { - здатність виявляти інтереси та нахили учнів для адек- } \\
\text { ватного підбору програм та методів навчання }\end{array}$ & КСП.02 \\
\hline $\begin{array}{l}\text { - здатність вивчати індивідуальні особливості учнів і } \\
\text { здійснювати ефективний психолого-педагогічний вплив } \\
\text { на них }\end{array}$ & КСП.03 \\
\hline
\end{tabular}




\begin{tabular}{|c|c|}
\hline $\begin{array}{l}\text { - здатність надавати допомогу у формуванні особи- } \\
\text { стості учня }\end{array}$ & КСП.04 \\
\hline $\begin{array}{l}\text { - здатність сприяти розвитку в учнів прагнення до за- } \\
\text { своєння нових знань }\end{array}$ & КСП.05 \\
\hline - здатність навчати будівельним наукам & КСП.06 \\
\hline $\begin{array}{l}\text { - здатність оновлювати зміст професійного навчання } \\
\text { відповідно до динамічних змін сучасної техніки та тех- } \\
\text { нологій }\end{array}$ & КСП.07 \\
\hline $\begin{array}{l}\text { - здатність до розроблення і впровадження освітніх } \\
\text { навчальних програм }\end{array}$ & КСП.08 \\
\hline $\begin{array}{l}\text { - здатність розробляти навчально-програмну та мето- } \\
\text { дичну документацію для теоретичного і практичного } \\
\text { навчання }\end{array}$ & КСП.09 \\
\hline - здатність складати тематичні та поурочні плани & КСП.10 \\
\hline $\begin{array}{l}\text { - здатність розробляти комплекси дидактичних засобів } \\
\text { навчання }\end{array}$ & КСП.11 \\
\hline $\begin{array}{l}\text { - здатність пояснювати новий матеріал доступними для } \\
\text { певного віку та індивидуальних особливостей засобами }\end{array}$ & КСП.12 \\
\hline $\begin{array}{l}\text { - здатність демонструвати професійні прийоми роботи } 3 \\
\text { матеріалами, інструментами, обладнанням }\end{array}$ & КСП.13 \\
\hline $\begin{array}{l}\text { - здатність здійснювати контроль за навчальними до- } \\
\text { сягненнями учнів }\end{array}$ & КСП.14 \\
\hline $\begin{array}{l}\text { - здатність організовувати та керувати практикою учнів } \\
\text { в умовах підприємств }\end{array}$ & КСП.15 \\
\hline $\begin{array}{l}\text { - здатність організовувати та керувати науково- } \\
\text { дослідною діяльністю учнів }\end{array}$ & КСП.16 \\
\hline $\begin{array}{l}\text { - здатність контролювати трудову та технологічну дис- } \\
\text { ципліну }\end{array}$ & КСП.17 \\
\hline $\begin{array}{l}\text { - здатність використовувати нормативні документи для } \\
\text { підвищення економічної ефективності технологічного } \\
\text { процесу }\end{array}$ & КСП.18 \\
\hline - здатність удосконалювати технологічні процеси & КСП.19 \\
\hline $\begin{array}{l}\text { - здатність контролювати дотримання визначеної тех- } \\
\text { нології виробництва }\end{array}$ & КСП.20 \\
\hline $\begin{array}{l}\text { - здатність експлуатувати обладнання галузі з дотри- } \\
\text { манням безпеки праці }\end{array}$ & КСП.21 \\
\hline $\begin{array}{l}\text { - здатність виконувати, розраховувати, контролювати } \\
\text { процеси відповідно до профілю підготовки }\end{array}$ & КСП.22 \\
\hline - здатність здійснювати виховну роботу з учнями & КСП.23 \\
\hline $\begin{array}{l}\text { - здатність використовувати методи психодіагностики } \\
\text { міжособистісних стосунків у навчальній групі }\end{array}$ & КСП.24 \\
\hline $\begin{array}{l}\text { - здатність проектувати, аналізувати та діагностувати } \\
\text { навчальний процес }\end{array}$ & КСП.25 \\
\hline - здатність аналізувати професійну діяльність фахівця & КСП.26 \\
\hline - здатність розробляти дидактичні технології & КСП.27 \\
\hline - здатність організовувати гурткову діяльність учнів & КСП.28 \\
\hline $\begin{array}{l}\text { - здатність використовувати елементи педтехніки, ме- } \\
\text { тоди саморегуляції, визначати стан учнів під час прове- } \\
\text { дення занять }\end{array}$ & КСП.29 \\
\hline
\end{tabular}




\begin{tabular}{|l|c|}
\hline $\begin{array}{l}\text { - здатність працювати з навчально-методичною літера- } \\
\text { турою }\end{array}$ & КСП.30 \\
\hline $\begin{array}{l}\text { - здатність визначати способи виховного впливу на } \\
\text { учнів в навчально-виховному процесі }\end{array}$ & КСП.31 \\
\hline
\end{tabular}

У проекті освітньо-кваліфікаційної характеристики бакалавра за напрямом підготовки 6.010104 «Професійна освіта. Будівництво» ми в табличній формі пропонуємо подати характеристику вище названих компетенцій через уміння, типові задачі діяльності та виробничі функції майбутнього педагога професійного навчання. Окремим додатком рекомендуємо подати таблицю, у якій би розкривалася сутність компетенцій майбутніх педагогів професійного навчання та система умінь, яка їх відображає.

У проекті освітньо-професійної програми в додатках у табличній формі доцільно запропонувати систему змістових модулів, під час вивчення яких формуються уміння, зазначені в освітньо-кваліфікаційній характеристиці.

Після цього доцільно подати додатками перелік навчальних дисциплін і практик та систему блоків змістових модулів; розподіл змісту освітньо-професійної програми підготовки, навчальний час за циклами підготовки, навчальними дисциплінами й практиками та перелік сформованих компетенцій; нормативні форми державної атестації, що використовуються для встановлення рівня засвоєння особами, які навчаються у вищих навчальних закладах, відповідних змістових модулів.

На нашу думку, такий підхід до стандартизації в освіті буде виправданим 3 позиції підготовки педагога професійного навчання нового покоління до роботи в сучасних умовах, здатного адаптуватися до педагогічних інновацій і швидко реагувати на сучасні й перспективні процеси соціальноекономічного розвитку суспільства. Тільки такий педагог професійного навчання в подальшій професійній діяльності буде формувати професійно компетентних кваліфікованих робітників.

\section{Література}

1. Кісіль М. В. До питання філософії стандартів у галузі вищої освіти / М. В. Кисіль // Науковий часопис НПУ імені М. П. Драгоманова. Серія №7. Релігієзнавство. Культурологія. Філософія: [зб. наук. праць]. - Випуск 12 (25). - К. : НПУ імені М. П. Драгоманова, 2007. - С. 207 - 214. 2. Клепко С. Компетенція стандарту: компетентність культури. Про концептуальні підходи до 